\title{
The Image of Russian Language \\ and Literature in M. Shishkin's Story \\ “Calligraphy Lesson": \\ Object and Unit of Translation
}

\author{
Veronica A. Razumovskaya* \\ Siberian Federal University \\ 79 Svobodny, Krasnoyarsk, 660041, Russia
}

Received 27.06.2016, received in revised form 15.09.2016, accepted 10.01.2017

\begin{abstract}
The article explores methodological (hermeneutical) problems of reconstruction of the information complex and unique linguocultural parameters of M. Shishkin's "Calligraphy Lesson" within the interlinguistic translation. The language and cultural features of the text created on the basis of leading postmodernism principles and devices, such as pastiche and deconstruction, together with the use of estranging considered as a method for the text arrangement and as a universal artistic law, reflect the author's individual style and dictate a necessity to combine culturally orientated strategies according to the literary translation tasks and purposes. A special attention is given to the literary translation units' identification, concerning which the translator makes their decisions, as well as to the determination of amount and systemic and structural organization of their form and content. In relation to the story's information, the heterogeneous translation hyper-unit can be represented by the image of Russian literature built on the image of Russian classical characters and graphic symbols of the Russian language. The analysis is conducted through the English translation of the story made by M. Schwartz.
\end{abstract}

Keywords: "strong" text, pastiche, estranging, cultural memory, literary translation, translation unit, translation strategies.

DOI: 10.17516/1997-1370-0046.

Research area: philology; culture studies.

Each epoch in the culture finds its standing reflection in fiction texts among which the most culturally and aesthetically important ones are defined as "strong" texts (Kuzmina, 2009), and their authors - as symbolic figures in the national and world literatures. The authors of "strong" texts, as a rule, serve as "messengers" of their literatures in the cultural panchrony and pantopoeia. Beyond any disputes, for the Russian culture such "messengers" were A.S. Pushkin, F.M. Dostoyevsky, L.N. Tolstoy, A.P. Chekhov and M.A. Bulgakov. Each period in the history of Russian literature has been marked by works of prominent writers, who reflected their contemporary world of the Russian culture and

(C) Siberian Federal University. All rights reserved

* Corresponding author E-mail address: veronica_raz@hotmail.com 
literature in the most accurate way possible (Goriunova, 2012).

A clear evidence for the "strength" of literary texts is their continuous large re-edition, inclusion in mandatory academic programs of different levels and also in their active part in crosscultural exchange and cooperation. Moreover, the "strength" can quite demonstratively be proved by a high degree of its re-interpretivity, i.e. by its translatability and translatedness, achieved through the performance of both "original" linguistic means and other linguistic or non-linguistic semiotic systems, which is in line with the intralinguistic, interlinguistic and intersemiotic types of translation according to Jacobson's classification (Jacobson, 1959).

In this respect, in must be also noted, that in certain circumstances together with the "strong" texts constituting the artistic heritage left by literary masters, the attention of readers, critics as well as philologists can retrospectively be targeted by earlier and, thus, less famous texts. Such return to "forgotten" texts is particularly reasoned by their authors' recognition. Like famous texts written by significant names in the culture and literature their earlier texts become objecsts of translation in cross-cultural and interlinguistic senses.

As the first published literary work by M. Shishkin (1993), the story "Calligraphy Lesson" has become a preview for his further works. The next 20 years of Shishkin's artistic career proved, that his first story was a "model of Shishkin's literature which clearly demonstrated the process of its decomposition on writing atoms, i.e. letters and symbols" (Orobii, 2011: 25). At that, it should be noted, that the publication of "Lesson" in the journal "Znamya" (lit. - "The Banner") has not gone unnoticed: the story went straight in the focus of literary critics (Mikheev, 1993; Shokhina, 1993). The career significance of the first work is also evident from the fact that his story collections translated into foreign languages appeared under the title "Calligraphy Lesson".

The title and story per se contain numerous allusions with precedent "strong" texts of the 19 and $20^{\text {th }}$ century Russian literature, which provides a wide presence in the text of the Russian literary and cultural memory. In its turn, a clear replication and text heterogeneity provide compelling evidence that the main literary device used by the author was pastiche - this fact was always mentioned by Shishkin scholars (Ingemasson, 2011).

Being familiar to the reader, characters of the Russian classical texts, whose names receive an important precedent status in "Lesson", and also those characters which are created by the author on their basis (anthroponomical blending) are given new features through the pastiche.

In the story's structure equally important role is played by another artistic approach, i.e. defamiliarization meaning creation of special forms and terms for a particular perception of the text by readers. Following V.B. Shklovskii who pioneered the notion of defamiliarization for the theory of literature and its adequate term for the literary analysis, this device allows the reader to keep their attention on the object described in the text, to perceive it emotionally, comprehend and then live through it. Defamiliarization implies creation of a specific perception and vision of the object which do not explain its meaning directly, but give an opportunity to concentrate the attention deliberately, increasing the length and complication in perception of the described object by the reader. "The image is aimed not at approximation of its meaning to our understanding, but at creating of a specific perception of the objects; at developing of its "vision" and not "familiarization" (Shklovskii, 1983: 20). This artistic device culminates in "Lesson" in colorful arguments by Calligrapher on the images of letters forming the Russian 
alphabet and on the associations they raise. In this context one may note about a "double" use of this approach. Firstly, defamiliarization is applied in the protagonist's speech to attract the attention of women talking to him in order to share his delight in contemplation and realization of the symbols beauty. Secondly, by using this device, the author also catches the reader's attention on the description of letters' images, what makes them both direct participants in these conversations and Calligrapher's followers.

Within the thematic polyphony of this short story, the theme of language and its written form in particular occupies a special place. Addressing to the ontological essence of the language, M. Shishkin in his first story, and then in the whole his heritage, marks the linguistic primacy due to its ability to model the human life in time and space. Thus, in his interview the writer speaks of inherent link between the language and literature. Their relationship is metaphorically defined as the relation between Jesus and Lazarus: the writer revitalizes a long dead language, inhaling new meanings in already existing words. The task for the writer who has acquired a poor or even dead language ("the language has gone as toothpaste") is to give this language its power and strength back. In the interview it is also emphasized that this point of view is true not only for the Russian language, but for language in its general meaning. Considering reading and writing as the main language activities, M. Shishkin notes that for him and his characters these activities are the ways to cope with the reality. All his texts tell us about the power of words, and all his characters are the author's metaphors (Gorski). It is interesting that Shishkin's experience in translation allowed him also to address his subjects of concern about the role of language and words in the man's fate from the perspective of a translator. Thus, the novel character of "Maidenhair" translates his fate into words and vice versa. The theme of translation (interpretation) holds a special place in Shishkin's works.

The text structure represents a series of conversations between a Russian calligraphy lover working as a court clerk (Engeny Alexandrovich) with several women (Sofia Pavlovna, Tatiana Dmitrievna, Nastasia Filippovna and Anna Arkadievna) during their training in calligraphy. Along with talks about calligraphy, the story also says (in the first person) about different events in the characters' lives. The conversations symbolize some kind of a set of independent plotlines which makes the narration fragmented and non-linear. Jumps and sudden changes between the plotlines create an impression of autonomous existence of each mini-novella. The non-linear nature of Shishkin's poetics clearly established just in his first story namely enables researchers to speak of a puzzle-principle in Shishkin's prose structure and in his choice of the narration strategy (Lashova, 2010).

It is interesting to note that for the protagonist a physical act of writing possess the same importance as the messages expressed by graphic signs. Through the spatial relations of graphical features of the writing symbols the character interprets nearness and distance between people and subjects; interconnection and indivisibility of things in the world. The court clerk thinks, that the man's nature and fate appear by their actions, speech and, what is particularly important for the court, by their handwriting. Through the writing both the author and lead character of "Lesson" interpret the man's life. "The fate here literally raises from the performance of writing, or when dictum turns into scriptum" (Ornobii, 2011: 30). As Engeny Alexandrovich understands, his environment is a text, a written discourse, which fully meets the ideas of postmodernism. One cannot but agree with A.V. Kubasov, who points out that "Lesson" "... integrates the hymn 
for fonts and writing together with its apologia" (Kubasov, 2015: 36).

The theme of language has frequently been stressed by the finest examples of the Russian literature, among whom N. V. Gogol and F.M. Dostoyevsky especially appeals to Shishkin. The language has also been addressed by the masters of the $20^{\text {th }}$ century. Thus, J. Brodsky's artistic heritage contains the author's conception of "philosophy of language" which grounds on the author's love and admiration of the language. M. Shishkin and J. Brodsky highly appreciate the role of language in the human fate. Thus, L. Shtutin, a translator, in his review on the collection of translated stories of M. Shishkin draws an analogy between Brodsky's poetic intention to free his readers from the vice of the Soviet reality brining them into linguistically "Other place" and, as in "Lesson" the protagonist's escape in the world of calligraphy, i.e. "another, higher world, a world of harmony, had wrested this space from that kingdom of worms" (Shtutin, 2015). As L. Shtutin marks, in Shishkin's story the art turns into a redemption, and the language gets the ability to free, lift us over the events and carry in a timeless space. The writer in his interview explains that for the court clerk, whose duty is to write down what happens in the cruel real world, calligraphy becomes a way of rebellion. The art indeed transforms Christ's agony into aesthetic experience and the horrible reality evolves into the beauty of art (Gorski).

The other central theme of this short is the idea of family and family relationships. Standing on a kind of "intersection" of realism and postmodernism, the story is definitely based on the main principle of post-modernism, i.e. on the principle of deconstruction. This very idea of familyundergoesinShishkin'stextdeconstruction, removal through the corresponding destructive motives of treason, death, killings, traitory, disease and insanity. Thus, just the first Shishkin's story implies the poetics of deconstruction peculiar to the later prose "...poetics of deconstruction in Shishkin's prose embodies destruction of the vertical component in the mental and spiritual life of the modern human and proves their value disorientation" (Kolmakova, 2014: 173).

Let's mention about another not less significant principle of the text's structure. It has been noted more than once that the thematic polyphony and complex stylistic organization (arrangement) are represented in the text of a small length (less than 7000 words). In the very first Shishkin's story one can find the author's intention for compression, which demonstrates his ability to increase the relative importance of words and take out additional connotations from it that indicates the writer's professionalism (Kubasov, 2015: 33).

The English-speaking readers have got acquitted with the story through the translation by $\mathrm{M}$. Schwartz famous also for her translations of M. Lermontov, I. Goncharov, N. Berberova and M. Bulgakov's works. The English version of "Maidenhair" was published in 2012 and then in 2013 it was included into the shortlist of candidates for the Best Book Translated into English award. At the present time M. Schwartz's translation is the first and only English translation of Shishkin's "Calligraphy Lesson". The translation was published in 2015 in M. Shishkin's stories collection of the same name and joined the list of 75 outstanding translations 2015 according to "World Literature Today". Right after publication, the collection received numerous reviews: "The collection consists of artfully constructed, empathetic tales of people living in the midst cyclonic time" ("New Orleans Review”, June 18, 2015); “... Shishkin draws divides between the humble and the sacred, the earthly and the spiritual" ("Music and Literature", June 18, 2015). The quality of translation was also noted in the reviews: "This extremely well- 
translated collection of fiction, memoirs and essays provides a useful point of entry, a summary of Shishkin's abiding themes and approaches over the first twenty years of his career" (“Times Literary Supplement”, July 17, 2015); “...Russian literature is bound up inextricably with the country's history, and that is no less true of this collection, which surely made the task of translating it formidable. But the artfulness of this translation helps it to surmount Shishkin's own claim that languages cannot communicate with each other" ("Dallas Observer", May 22, 2015). Cynthia Haven, a literary publicist from Stanford University, in her blog calls the attention to the importance of words in M. Shishkin's prose: "His prose breathes life - doesn't breathe it, gasps it, aware of the perishability of words, of worlds dying in each instant, and us dying with them, as life is beaten out of us second by second" (Haven).

The French translation, "La leçon de calligraphie", was made long before the English one (by K. Zeytunyan-Belous) and published in Paris within the anthology "Les Fleurs du Mal russe" in 1997. In 2005 in the anthology "La prose russe contemporaine" a new French version of the story was published. In 2009 the work was translated into Italian by E. Bonacorsi ("Lezione di calligrafia"). In comparison with "Lesson" other works by M. Shishkin are more successful in their translation history. Thus, the novel "Pismovnik" (lit. - "Letter Book") published in 2010, in 2015 was translated into more than 30 European and Oriental languages.

Proper names of the characters are wellknown to the Russian language and culture bearers. Moreover, such name-holders in Shishkin's work are not copied from the characters of famous Russian books. Thus, Engeny Alexandrovich is both Eugene Onegin, and Evgeny from "The Bronze Horseman" and Alexander Pushkin himself (as the middle name is
"Alexandrovich"), as well as the Prince Myshkin and Gogol's Bashmachkin (Ingemasson, 2011). "Literary" names of heroines belong to different authors, to texts of different epochs and styles, what is provided by the pastiche. In this sense, one can assume that, in Shishkin's work there are both several women with different histories and destinies, and one heroine who symbolizes a woman with a hard life and unhappy family.

Regarding a high degree of original allusiveness and necessity to stay focused on formal features of the text, M. Schwartz also claims about the ingenuity in narration and its insight into the Russian atmosphere. In this context, in the translator's note the attention is drawn to two important problems. Firstly, M. Schwartz mentions about different perceptions of personal names by the Russian and English speaking readers: if the ones can recognize the names of Russian classical characters at once, then for the others it is necessary to explain the source of names, what has actually been done in the note: “Sofia Pavlovna from Griboedov's play Woe from Wit; Tatiana Dmitrievna from Pushkin's long poem Evgeny Onegin; Nastasia Filippovna from Dostoevsky's Idiot; Anna Arkadievna from Tolstoy's Anna Karenina; and Larochka (Lara) from Pasternak's Doctor Zhivago". It is obvious here, that if the English-speaking readers do not know the initial source for these names and, thus, the nature of characters, then their acquaintance with the original authorship won't allow them to learn all the information related to the images of Russian literary characters and use this knowledge to decode Shishkin's text.

Secondly, M. Shwartz draws the recipients' attention to the fact that in a detailed description of calligraphy features of a specific Russian word "невтерпёж", a challenge for the translator is that the author describes each letter as an object of writing. In this way, the word's lexical meaning still stays important. 
Individual stylistic features of Shishkin's text set a number of complex challenges to its potential translator, successful solution of which gives an opportunity to create one of the central artistic images - the image of Russian literature - in the secondary text. Having heterogeneous structure, formed mainly by the combination of images of the Russian literature and language, the image of Russian literature arts has no concrete "geography" in the story's text. The image is created among the whole space of complex poetic structure of the story through the blending of different explicit and implicit means. Nevertheless, this image can methodologically be defined as a separate unit of literary translation regarding which the translator makes the decision (Razumovskaya, 2013; Razumovskaya, 2014).

Heterogeneous nature of the image with its pronounced cultural meaning and a variety of linguistic means used in its creation require choosing the most optimal culturally oriented translation strategies.

Every translation (regardless its type or object) is carried out according to the ad hoc principle. In this sense, it is highly important that literary translation includes three basic aspects: the linguistic aspect per se, cultural and temporal ones. The choice of translation strategies is closely linked to features of the language systems participating in the translation, to the period of time and cultural background of the texts. A necessity to consider the cultural context finally explains the appearance of strategies which respect the context directly. Such culturally oriented strategies were suggested and described by L. Venuti, who defined them as domestication and foreignization (Venuti, 1995)

The text of "Lesson" possesses explicit and implicit markers of the Russian culture. As it has been mentioned before, one of the central artistic images of the story is the image of Russian literature, characterized by a close connection with the Russian cultural space and considered to take a crucial part there due to a clear literary centralism of the Russian culture. M. Schwartz as an author of the first official English translation of "Lesson" was challenged by numerous cultural and linguistic tasks. A.V. Fedorov, a prominent Russian translation scholar, pointed out that "preservation of the national uniqueness of the original text, which means functionally correct perception and translation of the whole set of elements, is extremely difficult task both in practical and theoretical senses" (Fedorov, 2002: 378). One of the most complex challenges was the one related to graphical translation of the Russian word “невтерпёж”. In Shishkin's text one can find a detailed description of the process of its graphic image creation:

«Я и пишу: невтерпёж. И одно только слово-то чего стоит! Вы только попробуйте! Примитивная Н, может быть, и не стоит даже особого упоминания. Ее прямая палочка пишется по наклонной линии в один такт. <..> После закругления тонкая черта идет вверх, но не прямо, а дугообразно, слегка выгибаясь вправо, чтобы сразу, не отрываясь от бумаги, проникнуть в Е коварную простушку, невзрачную на вид, но требующую для достижения желаемого осторожности и умелого обхождения. После тупорылой казарменной Н для Е необходима легкая, куртуазная линия, которая, начинаясь почти ресничным штрихом с изгибом вправо, $<\ldots>$ С разлета перо устремляется ни много ни мало до верхнего угла следующей клетки, и любое дрожание или утолщение может моментально разрушить иллюзию этого свободного парения, которое с резким набором высоты превращается в В. Потайная суть этой верзилы вовсе не в сквозящих сверху и снизу пустотах, а в завершающем, неприметном с виду, но таящем опасности узелке с отчерком, за который уже нетерпеливо дергает 
T. Здесь важно не торопиться запечатлеть еще затягивающуюся петельку, а дождаться, когда узелок превратится почти в точку, тогда уже можно опрометью бросаться в три проруби подряд, благополучно снова возвращаясь в Е, Р и П - вовсе не буквы, а так, Г на палочке. Но дальше, дальше, в самом конце шествует Ж, эта удивительная членистоногая пава, единственная особа, разлагающаяся на целых пять тактов! В ней есть что-то и от двуглавого орла, и в то же время мягкие ее полуовалы крепко сидят на строчке, как на ступеньке. Она словно соединяет собой, будто зажим, расползающийся мир - небо и землю, восток и запад. Она изящна, совершенна, самодостаточна».

The English variant of this passage suggested by M. Schwartz is the following:

“That's what I wrote: fed up. Невтерпёж! What that one word costs! Just try it! The primitive $H$ may not merit special mention. Its crossbar is written on a slant in a single stroke. $<\ldots>$ After the curve the fine line goes up - not straight up but in an arc - bending slightly to the right so as not to lose contact with the page and break through to the $\ddot{e}$, a cunning ninny, unprepossessing to look at, but demanding caution and deft treatment in order to achieve the desired end. After the clumsy, snub-nosed $H$, the $e$ requires a light, graceful line that begins with an eyelash stroke and a bend to the right, $<\ldots>$ The merest tremble or thickening could instantly destroy the illusion of this free soaring, which takes a drastic gain in altitude to become a 6 . The secret essence of this spindleleg lies by no means in the spaces that run through it from top to bottom but in the concluding, unremarkable, but danger-laden sign-off loop beyond which the $m$ is already twitching impatiently. Here it's important not to be too hasty in imprinting the tightening loop but to wait for the loop to turn almost into a period. Then you can rush headlong into three holes in a row, returning happily once again to the $e, p$, and $n$, which is hardly a letter, just a 2 on a stick. But onward, onward, to the very end and the $\varkappa$, that amazing, anthropod peahen, the only one that falls into a full five beats! There's something of the two-headed eagle to it and at the same time its soft half-ovals sit firmly on the line, like on a perch. It seems to clamp an unraveling world together - heaven and earth, east and west. It's elegant, perfect, and sufficient unto itself'.

The comparative overview of original and translated texts demonstrates the fact that in order to express symbols of the Russian graphics the translator uses foreignization which involves orientation on the translating culture. To reconstruct the original cultural specificity in translation she preserves the original graphic for certain letters and the word "невтерпёж" per se (Cyrillic alphabet). For those recipients of translation who do not know the Russian language and its graphic system, letters of the Russian alphabet, introduced in the English text, visualizes the units of foreign language and facilitates understanding of the detailed description of Calligrapher's activity and his emotional attitude to the signs. The use of Cyrillic alphabet against the Latinic text is an example of defamiliarization, which catches the English-speaking reader's attention on the described object belonging to the foreign culture and raises sensuous and image sensitivity and experience in them.

The paradigm of culturally oriented translation units can also include the artistic image expressed both implicitly and explicitly. As for the M. Shishkin's story such element is the image of Russian literature representing in this case the object and unit of translation. The analysis of the modern English translation allows identifying particular translation methods and strategies which provide the most accurate and full reconstruction of the cultural potential of the original text and author's individual style. 


\section{References}

Fedorov A. V. (2002). Osnovi obshhei teorii perevoda (lingvisticheskie problemi) [Fundamentals of the general theory of trnalsation (linguistic problems)]. Saint-Petersburg, Filologicheskii fakultet SPbGU; Moscow, LLC Izdatelskii Dom "FILOLOGIA TRI", 416 p.

Goriunova I. (2012). Sovremennaia russkaia literatura: znakovye imena [The modern Russian literature: significant names]. Moscow, Vest-Konsalting, 162 p.

Gorski B. An Interview with Mikhail Shishkin. Available at: http://www.columbia.edu/cu/creative/ epub/harriman/june13/harriman_mag_june13.pdf

Haven C. Mikhail Shishkin, and what life does to us. Available at: http://bookhaven.stanford. edu/2015/07/mikhail-shishkin-and-what-life-does-to-us/

Ingemasson A.R. (2011). Khudozhestvennii mir rasskaza Mikhaila Shishkina «Urok kalligrafii» [The artistic world of M.Shishkin's story “Calligraphy Lesson”], In Izvestia Volgogradskogo gosudarstvennogo pedagogicheskogo universiteta [Volgograd State Pedagogical University Bulletin], 10 (64), 137-140.

Jakobson R. (1959). On Linguistic Aspects of Translation, In On Translation. Cambridge: Harvard University Press, 232-239.

Kolmakova O.A. (2014). Poetika dekonstrutscii v proze M. Shishkina [Poetics of deconstruction in M.Shishkin's prose], In Vestnik Kemerovskogo gosudarstvennogo universiteta [Bulletin of Kemerovo State University], 3 (59), 171-173.

Kubasov A.V. (2015). Na podstupakh $k$ esteticheskomu kredo Mihaila Shishkina (esse-traktat «Spasionnii iazyk) [At the foot to M. Shishkin's aesthetic credo (essay-treatise “The Saved Language”)], In Uralskii filologicheskii vestnik. Russkaia literatura XX-XXI vekov: napravleniia i techeniia [Ural Journal of Philology. The Russian literature in $20^{\text {th }}$ and $21^{\text {st }}$ centuries: directions and tendencies], 2, 33-46.

Kuzmina N.A. (1999). Intertekst i ego rol'v protsessakh evoliutsii poeticheskogo iazyka [Intertext and its role in evolution processes of poetic texts]. Yekaterinburg, Izdatelstvo Uralskogo univesiteta; Omsk, Izdatelstvo Omskogo gosudarstvennogo universteta, 278 p.

Lashova S.N. (2010). Printsip pazla: iazyk i khronotop v proze M. Shishkina [The puzzleprinciple: the language and chronotope in M.Shishkin's prose], In Vestnik Permskogo universiteta [Perm University Herald], 6, 186-190.

Mikheev A. (1993). Retsenzia na: Shishkin M. "Urok kalligrafii”. Rasskaz. (Znamya. 1993. № 1) [Review on: "Calligraphy Lesson”, the story by M. Shishkin. (Znamya. 1993. \#1)], In Novoie literaturnoe obozrenie [The modern literary review], 4, 334-335.

Orobii S.P. (2011). «Vavilonskaia bashnia» Mikhaila Shishkina: opit modernizatsii russkoi prozi ["The Tower of Babel" of M. Shishkin: the experience of modernization in the Russian prose]. Blagoveschensk: Izdatelstvovo BGPU, $161 \mathrm{p}$.

Razumovskaya V.A. (2013). Khudozhestvennie obrazi v romane M.A. Bulgakova «Master i Margarita»: problemi vospriiatiia i perevoda [Artistic images in M. Bulgakov's "Master and Margarita": problems of perception and translation], In Vestnik SVFU im. M.K. Ammosova [Journal of M.K. Ammosov North-Eastern Federal University in Yakutsk], 4, 79-85.

Razumovskaya V.A. (2014). Khudozhestvennii obraz kak edinitsa perevoda: bulgakovskaia Margarita [The artistic image as a translation unit: M. Bulgakov's Margarita], In Vestnik 
Cheliabinskogo gosudarstvennogo universiteta. Filologiia. Iskusstvovedenie. Vipusk 88 [Chelyabinsk State University Bulletin. Philology. Art studies. Issue 88.], 6 (335), 25-32.

Shklovskii V. (1983). Iskusstvo kak priem [Arts as a method], In $\mathrm{O}$ teorii prozi [On the theory of prose]. Moscow, Sovetskii pisatel, 9-26.

Shokhina V. (1993). Privet iz proshlogo: «Literaturnoe prinoshenie» Mikhaila Shishkina [Greeting from the past: "Literary contribution" of Mikhail Shishkin], In Literaturnaia gazeta [Literary Newspaper], 41, 4.

Shtutin L. Book review: Mikhail Shishkin, 'Calligraphy Lesson'. Available at: https://www. opendemocracy.net/od-russia/leo-shtutin/book-review-mikhail-shishkin-'calligraphy-lesson'

Venuti L. (1995). Translator's Invisibility: A History of Translation. New York, Routledge. $353 \mathrm{p}$.

\title{
Образ русского языка и словесности
}

\author{
в рассказе Михаила Шишкина \\ «Урок каллиграфии»:
}

объект и единица перевода

\author{
В.А. Разумовская \\ Сибирский федеральный университет \\ Россия, 660041, Красноярск, пр. Свободный, 79
}

В статье рассматриваются методологические (герменевтические) вопросы реконструирования в межъязыковом переводе информационного комплекса и уникальных лингвокультурных параметров рассказа «Урок каллиграфии» М. Шишкина. Языковые и культурные особенности текста, созданного на основе ведущих постмодернистских принципов и приемов пастиша и деконструкиии, а также с использованием остранения как приема организации текста и универсального закона искусства, отражают идиостиль автора художественного оригинала и диктуют необходимость комбинирования культуроориентированных стратегий в соответствии с иелями и задачами художественного перевода. Особое внимание в работе уделяется выделению единии художественного перевода, относительно которых принимается решение на перевод, а также установлению объема и системно-структурной организации формы и содержания потенциальных единиц перевода. В отномении информации анализируемого рассказа к гетерогенной гиперединище перевода может быть отнесен образ русской словесности, формируемый образами персонажей русской классической литературы и графическими символами-образами русского языка. Материалом анализа стал английский перевод рассказа, выполненный М. Швари.

Ключевые слова: «сильный» текст, пастиш, остранение, культурная память, художественный перевод, единица перевода, стратегия перевода.

Научная специальность: 10.00.00 - филологические науки; 24.00.00 - культурология. 